Meta

Journal des traducteurs

Translators' Journal

\title{
European Community Translation in Belgium
}

\section{Peter J. Arthern}

Volume 39, numéro 1, mars 1994

La traduction et l'interprétation dans la Belgique multilingue

URI : https://id.erudit.org/iderudit/001908ar

DOI : https://doi.org/10.7202/001908ar

Aller au sommaire du numéro

Éditeur(s)

Les Presses de l'Université de Montréal

ISSN

0026-0452 (imprimé)

1492-1421 (numérique)

Découvrir la revue

Citer cet article

Arthern, P. J. (1994). European Community Translation in Belgium. Meta, 39(1), 150-158. https://doi.org/10.7202/001908ar

\section{Résumé de l'article}

Les institutions de la Communauté européenne, situées en Belgique, doivent composer avec plus de 9 langues de travail. De ce fait, le travail de traduction effectué dans ces institutions constitue la majeure partie de l'activité de traduction en Belgique. Cet article présente les différentes institutions de la Communauté et l'activité de traduction qui s'y déroule. 


\section{EUROPEAN COMMUNITY TRANSLATION IN BELGIUM}

PETER J. ARTHERN

Council of the European Community, Brussel, Belgium

\section{Résumé}

Les institutions de la Communauté européenne, situé en Belgique, doivent composer avec plus de 9 langues de travail. De ce fait, le travail de traduction effectué dans ces institutions constitue la majeure partie de l'activité de traduction en Belgique. Cet article présente les différentes institutions de la Communauté et l'activité de traduction qui s'y déroule.

\section{THE EUROPEAN COMMUNITY INSTITUTIONS}

With their nine working languages (Danish, Dutch, English, French, German, Greek, Italian, Portuguese and Spanish) the European Community institutions located in Belgium must account for a large proportion of overall translation and interpretation activity in that country. However, we shall not discuss interpreting in this article, which is restricted to considering translation in the Community institutions and other Community bodies in Belgium, together with "outside" translation placed on the Belgian market.

The various European Community institutions and other bodies are all located either in Brussels or in Luxembourg, some of them being split between the two cities. Brussels is the seat of the Council, of the Commission and of the Economic and Social Committee while the European Parliament, the Court of Justice, the European Investment Bank and the Court of Auditors are situated in Luxembourg. The Commission has a number of Directorates General located in Luxembourg and conversely the European Parliament has offices in Brussels in which meetings of the Parliament's committees are held.

\section{EUROPEAN COMMUNITY BODIES IN BELGIUM}

Because of their geographical distribution only three Community bodies have a permanent ongoing translation activity in Belgium (Brussels); they are:

The Commission

The Council

The Economic and Social Committee.

Roughly five-sevenths of the Commission's in-house translation activity takes place in Belgium, the rest being carried out in Luxembourg. All the Council's translation activity, and all the Economic and Social Committee's translation, are carried out in Brussels.

There is also a fourth, Community-centred translation service located in Brussels, the ad hoc Translation Division set up to serve the 1985 Schengen Agreement between the Governments of the States of the Benelux Economic Union, the Federal Republic of Germany and the French Republic on the gradual abolition of checks at their common borders.

In addition, the Western European Union which, under the Maastricht Treaty, is an integral part of the further development of the European Community as regards decisions 
and actions which have defence implications, moved from London to Brussels in January 1993.

\section{THE COMMISSION}

With some 1,200 linguists (translators, revisers and terminologists) and 550 supporting staff (secretaries, typists, archivists, etc.) the Commission of the European Community has the largest Translation Service in the world. Two of its seven subject-based production units are located in Luxembourg. The other five production units serve the Commission's Directorates General in Brussels. Following a complete overhaul of the Commission's Translation Service in 1990, each production unit is composed of nine single-language groups (one for each working language) consisting of 15 to 20 linguists (translators and revisers).

Each single-language group is headed by the equivalent of a "head-of-unit" in the sense given to that term in the Commission's new middle management system, of grade L/A 5, L/A 4 or L/A 3. In the new structure there are therefore $7 \times 9=63$ "head-of-unit" posts as against the 18 Heads of Division in the old structure, nine in Luxembourg and nine in Brussels. As this new structure was fitted into place the Translation Service managed the demand for translations by working in much closer co-operation with its customers, the Directorates General, so as to unify the two processes of drafting documents and then translating them. This was done in two ways.

Firstly, a computerised progress-chasing system was installed to monitor the workload which the Translation Service can carry, and to quantify demand in terms of the various types of translation which are requested and customers' deadlines. The Directorates General are asked to fix relative priorities for different translations which they are requesting. Each Directorate General was asked to appoint an official to be responsible for contacts with the Translation Service.

Secondly, a "Translation Guide" was issued to the Directorates General so as to facilitate dialogue between their officials and the Translation Service (Co-ordinators and Central Planning Unit). In addition, officials drafting documents were asked to write shorter texts, in simpler, clearer language, and to supply the Translation Service with any reference documents which they have used. Repetitive texts such as those relating to the functioning of the internal market (calls for tenders, notification of standards, technical rules), for example, are already being progressively standardised.

The new management structure of the Translation Service is both "vertical" and "horizontal". The Co-ordinator heading each production unit ensures that translations are produced within the deadlines agreed with the Directorates General which are his or her customers and that the various language versions of a given document are concordant. Within each production unit the heads of the single-language groups are of course responsible for every aspect of their group's work.

In addition to this vertical structure of seven independent production units there is a Directorate responsible for "horizontal" management across all these units. In this Directorate there is a language co-ordinator for each language who is responsible for ensuring the quality of translations (accuracy, correct and consistent use of terminology, style, level of language appropriate to a particular text) in his or her language groups in all seven production units. The language co-ordinator for a given language is also responsible for maintaining contacts between his or her linguists and for recruiting staff to translate into that language. This Directorate is also responsible for sending translation work out to translation companies and freelances. 
The approximate output of the Commission's Translation Service in Brussels for all nine languages added together was 47,250 pages in January 1993 and 56,440 pages, including 7,059 pages translated by translation companies and freelances, in February 1993.

\section{Outside translation}

In $1990 \mathrm{Mr}$ Eddy Brackeniers, the new Director General of the Commission's Translation Service, was asked if the Commission intended to continue sending translation work out to translation companies and freelances. He replied that the Commission's translation requirements were continuously increasing and that it would be counter-productive to attempt to carry out all the Commission's translation activities in-house.

In effect, he said, there are many texts which can only be translated in-house because the translators need to have close contact with the authors and must follow strict guidelines, as when translating proposals for Community legislation which are going to be submitted to the Council. These are the texts whose preparation must be regarded as a joint operation between the drafting Directorates and the Translation Service. Other texts can be translated outside. Among these are all the texts involved in the day-to-day running of the single market, such as calls for tenders, technical rules, reports, and studies on an infinite variety of subjects.

\section{Register of qualified translators}

Since Mr Brackeniers made this statement in 1990 the Commission's Outside Translation Department, working closely together with the European Parliament's Translation Service, has been engaged in creating a register of freelance translators and translation companies and agencies willing to provide translations on request under clearly defined conditions.

The first step was to advertise widely in all twelve Member States of the European Community, inviting translators and translation organizations, as they were termed, to complete a registration form as an expression of their interest in providing the Commission with translations under contract. The form for individual translators called for information on the translator's personal details; any existing contacts with European Community Institutions; education; knowledge of languages; specialization; previous employment and the translator's equipment and translation aids.

The form for translation organizations called for details of the organization (company, agency, etc.) and of its structure and operating methods; any existing contacts with Community Institutions; language combinations; specialization; experience and references; equipment and translation aids; declarations concerning the organization's VAT and tax status, etc.

The first selection stage, completed in 1992, produced about 3,000 expressions of interest. Around 1,800 candidates (1,450 individuals and 350 organizations) were "prequalified" on the basis of the forms which they had submitted and were then sent a test translation for each language combination which they had indicated on their application form. The resulting 5,000 or so translated texts were reviewed by the Translation Services both of the Commission and of the European Parliament, all the individual assessments being entered in a specially created data base. All these organizations and individual translators will receive a letter informing them of the result of their application and those who have passed a test will be asked for price quotations for the translation of texts in the language combinations in which they had succeeded.

The Commission will then make counter-offers to each organization and individual translator. Organizations and individuals which agree to work for the Commission at the prices given in the counter-offers will be placed on a Register and may then be selected to provide specified translations for the Commission or the European Parliament in due course, according to the needs of the two Institutions. 


\section{Current outside translation activity}

While preparing the above Register the Commission has continued to send an increasing proportion of its translation work to outside translators and organizations, incuding some of the large translation companies in Belgium. As already stated, the total output of the Commission's Translation Service in Brussels in February 1993, for all nine languages added together, was 56,440 pages - including 7,059 pages, i.e. $12.5 \%$, translated by freelances and translation organizations.

In the previous year, 1992, the Commission spent a total of 3,900,000 ECU on outside translations produced in the European Community, $40 \%$ of which was spent on the Belgian market, and some $600,000 \mathrm{ECU}$ on the typing of translations ( $80 \%$ of which was done in Brussels).

\section{Terminology}

Another area in which the Commission plays an important role on the translation market in Belgium is that of terminology. The Commission's Terminology Unit operates the "Eurodicautom" terminology data base containing many thousands of terms in all of the Community's nine working languages. This is made available on line, free of charge, to translators and translation organizations who are working for the Commission, as is the Commission's "Celex" data base, containing full-text records of all Community legislation. The Commission also produces printed glossaries in various language combinations and on various subjects, which are on sale to the public.

The Commission's Outside Translation Unit had hoped to encourage outside translators and translating organizations to record any terminology which they developed on their own account, and to make it available to the Commission. In fact it has not yet proved possible (by the summer of 1993) to do anything systematically in this area, although the Commission still intends to pursue this initiative.

\section{THE COUNCIL}

The whole of the Council Secretariat is located in Brussels. With a total staff of some 2200 officials its function is to service all the meetings of the Council and of the Permanent Representatives of the Member States, plus the many meetings of government experts which are held during the process of enacting Community legislation.

There are usually one or two Council meetings each week, in which the Member States are represented by their Ministers having responsibility for the subject under discussion, such as "Labour and Social Affairs", "Energy and the Environment", "Agriculture", "Research", "Justice", to name but a few. Each week the Permanent Representatives (the Minister's deputies, located permanently in Brussels) meet for two days and every day there are several meetings of experts. In all, there are usually ten or a dozen meetings held on the Council Secretariat's premises every working day.

\section{Language policy}

At the beginning of the Council's operations, in 1958, it was enacted by Regulation No 1 determining the languages to be used by the European Economic Community that each of the four languages in which the Treaty of Rome had been drafted (Dutch, French, German and Italian) was to be an official language, and also a working language. It was also laid down that "Regulations and other documents of general application" were to be drafted in the four official languages.

The principle of using all official languages as routine working languages, known as the "régime linguistique intégral", was introduced at the time of the first enlargement 
of the European Community (Denmark, Ireland and the United Kingdom in 1973). Since then there have been two further enlargements, (Greece in 1981, Spain and Portugal in 1986) with the result that the European Community now has ten official languages, i.e. Danish, Dutch, English, French, German, Greek, Irish, Italian, Portuguese and Spanish and that all of them except Irish are also working languages. Consequently the Council Secretariat has to provide documents for all the meetings referred to above in all nine working languages, together with other administrative and political documents as the need arises.

\section{The Translation Department}

To meet this requirement the Council's Translation Department currently employs some 435 linguists, organized in nine separate Divisions. There are about 50 linguists in each Division, except for the French Division, which is smaller than the others as some two-thirds of Council documents are drafted in French. Each Division has a small typing pool attached to it, which provides secretarial assistance to linguists in preparing their translations. Final typing of most documents is done in the corresponding "Main Pools", which also work for other departments of the Secretariat.

When a member of the Secretariat's staff needs to have a document translated from the original version into other working languages he puts in a request to the General Coordination Office, responsible for co-ordinating all aspects of the production of documents, which passes it on to the Linguistic Co-ordination Office in the Translation Department. Here, staff check the accuracy of the information supplied with the request, to see whether relevant reference documents have been indicated, and whether the translation deadline can be met. When all these conditions are satisfied the document is sent to the various Language Divisions for translation.

The Language Divisions operate independently of each other, as nine parallel production lines, but give each other all necessary assistance in such areas as providing reference documents and help with terminology. Each Division has its own structure, centred on its "local co-ordination" office which receives the work sent on by the Linguistic Co-ordination Office and distributes it to translators and then to revisers.

As a matter of principle, all texts translated in the Council Secretariat are revised by a second linguist before being sent to the Typing Pool for typing. Typed texts are not returned for checking, the Pool being responsible for the correct typing of all documents.

The texts of all legislation enacted by the Council are given a final reading by a Working Party of Legal Linguists, from a Legal Linguists Division which is attached to the Secretariat's Legal Directorate, before being published in the Community's "Official Journal" which appears in nine separate language editions.

\section{Archives}

Because a large amount of the Translation Department's work consists of translation of documents relating to legislative texts submitted by the Commmission (usually in the Community's nine working languages) there is a great deal of reference back to earlier texts. For this reason each Division has its own Archives, with three or four " $\mathrm{C}$ " grade staff, where several copies of all Council documents are kept, in French and English and in the Division's own language.

A Division's Archives also contain the following series of documents, among others, all of which are required more or less frequently as reference material or source material for translations.

- The Official Journal (O.J.) of the European Communities;

- Court Reports of the European Court of Justice; 
- European Parliament documents;

- Collected Acts of the various Association Agreements.

All Archives can also trace documents relating to a given subject, either via a card index or a computerized index. In this connection at least one Division also files copies of all documents in suspended files under subject matter headings.

In addition to complete Council documents, linguists also need both wider and narrower sources of information, provided by the Division's Library and its Terminology Service respectively.

\section{Library}

Each Division has its own reference library, usually run by a volunteer linguist, perhaps assisted by "C" staff from time to time. The Library has an annual budget which can be used for buying dictionaries and other reference works, and also for subscribing to relevant periodicals. Staff can come to the Library at any time and can ask the librarian for advice and assistance in tracking down the information they need.

\section{Terminology}

The Council Secretariat has its own computerized terminology System (TIS = Terminological Information System) run on a mainframe computer in the Charlemagne building, with several terminals serving each Translation Division. Typically one or two of these terminals will be located in the Division's Library while there will usually be at least one on each floor of the building occupied by the Division.

Each Division has one full-time terminologist (or two linguists sharing this function) assisted by volunteer linguists who provide an S.O.S. service in the Division's Terminology Office (usually in the same room as the Library). As a result, a linguist who needs to know the equivalent in his own language of a term found in the document he is translating can either interrogate TIS on the terminal on his floor, or in the Terminology office, or can ask the terminologist on duty to find the correct term for him. The terminologists in each Division enter all new terms in TIS as they are found, so that they are immediately available to other linguists who require them.

Each Division in the Council's Translation Department also has on-line access to "Eurodicautom", the Commission's terminology data-base and to "Celex", its data-base relating to published Community legislation.

\section{Work load}

Since the Council Secretariat exists solely to service the meetings involved in carrying out the Council's function of enacting Community legislation, the Translation Department's work load varies in proportion to the number of meetings being held. Each Member State holds the Council Presidency for six months in turn, with the bulk of its work naturally tending to be concentrated towards the end of its six-month term of office. There is also usually a break in the Presidency's activities around Easter, so that there are normally three peaks in translation activity each year, in March, or April, June and November.

The current picture of "source languages", i.e. the languages in which documents are drafted within the Council Secretariat, is approximately 65\% drafted in French, 30\% drafted in English and 5\% for the seven other languages taken together.

From July to December 1992 the average monthly output of a typical Language Division was some 4,500 pages, with the smaller French Division producing about 2000 pages per month and the English Division lying in between these two figures with around 3,600 pages per month. 


\section{THE ECONOMIC AND SOCIAL COMMITTEE}

The Economic and Social Committee is an advisory body established by Article 193 of the Treaty of Rome. It must be consulted by the Council or by the Commission where the Treaty of Rome so provides and these institutions may consult it in all cases in which they consider this to be appropriate. The Committee can also issue "own-initiative" Opinions when it sees fit to do so.

The Committee consists of 189 members from all the Member States together, representing the various major national interest organizations. Members are divided into three groups (employers, workers, other interests) and at the same time into nine Specialized Sections relating to the principle fields covered by the Treaty of Rome.

In practice, the Economic and Social Committee is required to forward its Opinion on proposals for new Community legislation to the Council and to the Commission. The Committee's Opinions are agreed in a monthly plenary session on the basis of a proposal drafted in the relevant Specialized Section.

The language in which a particular Opinion is originally drafted is usually the language normally used by the "rapporteur" of the Section in question, or by the Committee official who prepares a text for the rapporteur. In addition, there are many internal administrative texts, drafted in various languages. The Committee's Translation Service therefore has to be able to translate from all nine Community languages into the other eight.

Averaged over the five years from 1987 to 1992, the percentages of its total input which were received in the various languages were:

$\begin{array}{lr}\text { French } & 50.64 \% \\ \text { English } & 19.9 \% \\ \text { German } & 11.16 \% \\ \text { Italian } & 8.8 \% \\ \text { Dutch } & 3.46 \% \\ \text { Spanish } & 2.4 \% \\ \text { Portuguese } & 1.9 \% \\ \text { Greek } & 0.96 \% \\ \text { Danish } & 0.78 \%\end{array}$

As in the Council's Translation Service the Economic and Social Committee has a separate Language Division for each of the European Community's nine working languages, averaging 13 linguists for each language except French, for which there are 11 linguists. There is also a Typing Pool for each language, responsible to a Head of Pool, all the Pools being responsible to a joint Head.

In practice, many translators are now typing directly into a personal computer in their own office, but the traditional freedom of choice is regarded as sacrosanct, so that a translator may also choose to write a text longhand, to type it on a typewriter or to dictate it on a dictating machine. However it is produced, the translator's text becomes available on paper for revision.

As would be expected, all the Divisions except the French Division produce approximately the same annual output. The actual figures averaged over the three years 1990-1992 for the annual output of the various Divisions, expressed in "full pages" are:

$\begin{array}{lc}\text { French } & 7,590 \\ \text { German } & 12,063 \\ \text { English } & 11,599 \\ \text { Dutch } & 11,010 \\ \text { Italian } & 10,730\end{array}$




$\begin{array}{ll}\text { Danish } & 10,684 \\ \text { Greek } & 10,982 \\ \text { Spanish } & 11,587 \\ \text { Portuguese } & 10,961 .\end{array}$

Each Language Division has its own documentary Archives in which relevant "ownlanguage" documents and reference books are kept. The Translation Service as a whole maintains central Archives in which all Committee texts required for current translation activities are held in all nine languages. Again, like the Council Secretariat, the Economic and Social Committee's Translation Service makes full use of two of the Commission's data bases - Eurodicautom (terminology) and Celex (Community legislation), as well as keeping its own terminology records.

\section{THE "SCHENGEN" TRANSLATION SERVICE}

This Brussels-based Translation Service forms part of the Secretariat serving the "Schengen" Agreements on the gradual abolition of checks at the borders between the States Parties to the Agreements. The original Schengen Agreement of 14 June 1985 was negotiated by the Benelux countries (Belgium, The Netherlands and Luxembourg), together with France and Germany, as a contribution to regulating the free movement of persons across the internal borders of the European Community under the 1992 Single Market project. In practice it was soon found that the Agreement required substantial amendment and the necessary changes and amplifications were incorporated in the Schengen Convention of 19 June 1990 applying the original 1985 Schengen Agreement.

Although most of the other Member States of the European Community have since acceded to the Schengen Agreement and Convention (Italy in 1990; Spain and Portugal in 1991; and Greece in 1992), the United Kingdom, Ireland and Denmark have not done so. Consequently the Schengen Secretariat is not legally a Community institution although it relates to an aspect of Community policy, the free movement of persons, which is referred to in Title III of the Treaty of Rome. The free movement of persons is also referred to in Article KI of the Maastricht Treaty which states, among other things, that the Member States (of the European Community) are to regard rules governing the crossing by persons of their external borders, and the exercise of controls thereon, as matters of common interest. It therefore seems logical to regard the translation activities of the Schengen Secretariat as being performed within the European Community ambit.

The current situation is as follows. Since neither England, Ireland or Denmark have acceded to the Schengen Agreements the Secretariat does not use either English or Danish as a working language. The Translation Service has a separate translation unit consisting of four linguists for each of the other seven European Community languages (Dutch, French, German, Greek, Italian, Portuguese and Spanish).

\section{Unusual features}

The Schengen Translation Service has two unusual features, the first being that two of the four linguists in each unit double as interpreters as well as translators. When working as interpreters these linguists service a maximum of four meetings each week between them at various levels, from the six-monthly Schengen ministerial meetings to expert working parties on various subjects. The interpreters also give daily briefings on progress in the meetings to their translator colleagues. The second unusual feature, as compared with the Community institutions, is that the Service expects translators to type all their own texts to the stage of final printing, without any secretarial help. 


\section{Translation operations}

Revision is selective. All texts for ministerial meetings and for the "Groupe Central" (monthly meetings of senior officials) are revised but below this level the Head of the Service decides which texts need revision. A translator may also recommend that a given text should be revised. Texts are revised on paper and the reviser then discusses proposed changes with the translator. When agreement is reached on the changes to be made the translator types them into the word-processing system where the final text is available to the secretary of the administrator who has requested the translation.

Like the Council of the European Community the Schengen system has a rotating six-monthly Presidency, but as there are only nine States Parties to the Agreement, as compared with twelve Member States of the Community, the Schengen Presidency is not usually held by the Member State holding the Presidency of the European Community Council.

The "source language" of documents sent to the Schengen Translation Service depends very much on the language of the current Presidency. For example, with the current Spanish Presidency (January to June 1993) about half the texts arriving for translation are drafted in Spanish. Whatever the source language, all texts are translated into all the other six Schengen languages.

With the small number of linguists translating into each language this great variation in source language means that each translator has to be able to work into his or her mother tongue equally well in principle from at least three other Schengen languages. English can also be accepted as a source language. Linguists who are recruited as translators/ interpreters have to be able to interpret and translate into their mother tongue from two other Schengen languages on recruitment. Because it is difficult to recruit translators who can already work equally well from four languages the Translation Service runs language courses on two evenings each week which new recruits have to attend until they have reached the required level of proficiency. After two years service, translators are required to work from four Schengen languages other than their own, and interpreters from three.

Translators are also required to maintain a high level of output, from whatever language they are working, expressed as 210 lines of translation per day. In order to make the best use of linguists' varying abilities and specialized knowledge the Head of the Service allocates documents for translation to each linguist, and reviews their progress each day.

Working under these conditions, i.e. from all seven Schengen languages, the Schengen Translation Service is currently producing some 350 pages of translation per month into each of the seven languages, a page being taken as 30 lines of newly-translated text.

\section{THE WESTERN EUROPEAN UNION}

As already mentioned The Western European Union has been located in Brussels since January 1993, and can be regarded as at least the potential defence arm of the European Community as it becomes The European Union under the Maastricht Treaty.

The Western European Union Secretariat has only two working languages, English and French. There is a small Translation Service consisting of three linguists working into French and two into English. The documents they are required to translate relate either to the WEU's political or military activities or to the Secretariat's internal administration. The average total monthly output of translation (English plus French) in 1992 was 170 pages.

In addition to translation, however, the linguists are heavily involved in helping administrators to draft working documents and communiqués, sitting with them during the meetings themselves. They also edit administrators' texts drafted after meetings. This function is similar to the précis-writing activities carried out by linguists in the United Nations Translation Service in New York. 